\title{
Development Of Waqf Based Microfinance And Its Impact In Alleviating The Poverty
}

\author{
Aulia Arifatu Diniyya ${ }^{1 *}$ \\ ${ }^{1}$ IIUM Institute of Islamic Banking and Finance, \\ International Islamic University of Malaysia \\ *e-mail: aulia.arifatu@live.iium.edu.my
}

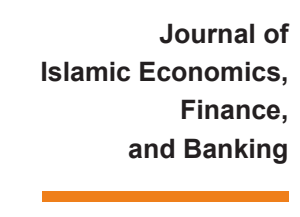

Vol. 2, No. 2, Desember 2019 ,

\section{Abstract}

The purpose of this paper is to discuss the potential role of the institution of Waqf in poverty alleviation. Poverty is a complex, multi-dimensional phenomenon that has captured the attention of numerous scholars and agencies globally. The social role of the Islamic financial sector can be best exemplified by providing finance to the poor to increase their income and wealth. This paper will explore on how microfinance can be provided on Shariah compliant basis through Waqf model. This research also reviewing the development of the integrated Waqf based Islamic microfinance which aimed to provide solutions to reduce poverty. An integration of Waqf-based Islamic microfinance (IWIM) model is proposed to address all the practical challenges of microfinance faced in Muslim communities. In this model, microfinance is practised in compliance with Shari'ah to address the multi-dimensional aspects of poverty and empowering the poor in order to enhance the socio-economic development and hence the well- being of the Ummah. With this aspiration, the IWIM model aims to tackle the challenges related to the scarcity of capital, inadequate human resources, absence of proper Takaful programs and project financing in an integrated approach. However, Waqf based microfinance still may be facing some problems should be addressed which related to credit risk, moral hazard, and economic viability.

Keywords: Waqf, Poverty alleviation, and Microfinance

\begin{abstract}
Abstrak
Tujuan dari makalah ini adalah untuk membahas peranan lembaga wakaf dalam pengentasan kemiskinan. Kemiskinan adalah fenomena kompleks multi-dimensi yang telah menarik perhatian banyak peneliti dan lembaga- lembaga di seluruh dunia. Memberikan pembiayaan kepada masyarakat miskin untuk meningkatkan kesejahteraan mereka adalah salah satu contoh peranan sosial dari sektor keuangan Islam. Makalah ini akan mengeksplorasi tentang bagaimana keuangan mikro dapat disediakan berdasarkan Syariah berbasis Wakaf. Penelitian ini juga
\end{abstract}

Ihtifaz: Journal of Islamic Economics, Finance, and Banking

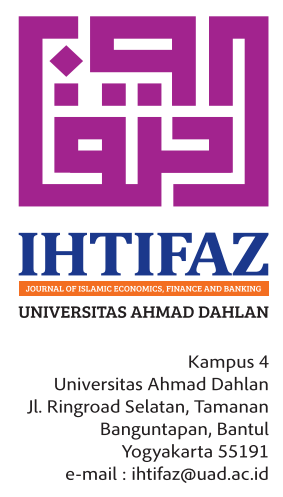


mengkaji perkembangan keuangan Islam mikro berbasis wakaf terintegrasi yang bertujuan untuk memberikan solusi untuk mengurangi kemiskinan. Integrasi IHTIFAZ - JIEFB model keuangan mikro Islam berbasis wakaf (IWIM) diusulkan untuk mengatasi semua tantangan praktis keuangan mikro yang dihadapi dalam komunitas Muslim. Dalam model ini, keuangan mikro dipraktikkan sesuai dengan Syariah untuk mengatasi aspek multi-dimensi kemiskinan dan memberdayakan orang miskin untuk meningkatkan pembangunan sosial-ekonomi dan kesejahteraan umat. Dengan aspirasi ini, model IWIM bertujuan untuk mengatasi tantangan terkait dengan kelangkaan modal, sumber daya manusia yang tidak memadai, tidak adanya program Takaful yang tepat, dan pembiayaan proyek dalam pendekatan terpadu. Meskipun demikian, keuangan mikro berbasis wakaf masih menghadapi beberapa masalah yang harus diatasi yang terkait dengan risiko kredit, permasalahan moral hazard, dan kelayakan ekonomi.

Kata Kunci: Waqf, Poverty alleviation, and Microfinance

\section{INTRODUCTION}

The word Waqf is derived from the Arabic root or in verb Wakafa, means "causing the thing to stop and standstill". Besides that, it also means to hold, detain or keep. According to Ibrahim (2008), Waqf refers to the detention of a specific thing in the ownership of Waqf and focusing on its profits or benefit in charity for the poor or other good intention.

Waqf means detention of a property so that its product or income may be always available for religious and charity purpose. The concept of Waqf was developed by the Holy Prophet Muhammad SAW and had played an essential role in fulfilling the needs of socio-economic of the Ummah.

Apart from religious purposes as building a mosque, Waqf has played a significant role in the socio-economic area. During the Ottoman empire, Waqf was the main contributor to the financing of education, health and welfare of the general public. In another incident, Prophet S.A.W called for the purchase of a well and turned it into Waqf to as a solution to a water shortage issue faced by the public.

Poverty and income inequality have always been among the most critical and enduring problems that the societies face. There are ways to handle poverty problems, starting from preventive to curative measures. Charity is a meaningful way to alleviate poverty as considered by Sadeq (2002) which has been playing a role and can potentially be an effective means to overcome these acute problems. The charity has many forms, but a long-lasting form of charity is one that has the characteristic of perpetuity. The institution of Waqf is such a perpetual charity in the Islamic system. In general, the well-managed Waqf properties would enhance economic progress in the country. The Waqf institution was flourishing, the country's economy was also advancing. The bigger the size of Waqf properties, the bigger the extent of private sector involvement and more progress of the economy. 
Contemporary microfinance evolved after developmental policies of the 1950 s and 1960s failed to eradicate poverty. The poor generally lack access to financial services, and it is believed that microfinance will give

good development in social economic. Waqf based can be a microfinance activity globalization era where the Islamic financial services have been developed among the Muslim countries. Microfinance institutions, nongovernmental organizations (NGOs) and various government schemes pp. 107-123, ISSN p:2622-4755 that focus on poverty reduction are the potential platforms for the implementation of the IWIM model in Muslim countries and communities. Islamic microfinance is the provision of financial services for low-income populations in which the services are provided in conformity with Islamic financing principles. Besides, Waqf has the potential of utilizing their proceeds for positive socio-economic development of the poor.

\section{METHODOLOGY}

The study is using library research. It reviews the literature on the issues of accessing the Waqf as a source of microfinance to eradicate poverty. Waqf and Islamic microfinance reviewed critically to propose an integrated Waqf based microfinance as an alternative model.

\section{LITERATURE REVIEW}

\section{Waqf and Islamic Microfinance: Nature, Uses/implementation and Development}

The general concept of Waqf involves the donor who gives away his private property and stipulates the conditions for the uses of the property and the funds of which it generates. He either manages the Waqf property himself to ensure the intended fund flow is realized or appoints a trustee on his behalf. In doing so, the Waqf becomes irrevocable, inheritable and unsaleable. In other words, the ownership title is no longer the donors. This point to the literal meaning of Waqf that is "to stop". In other words, the Waqf property can now only be used for the established purpose permanently and perpetually.

The origins of Waqf started way before the advent of Islam (Sadeq A.M., 2002). The ancient nations used to endow their properties and made them places of worship. One of the rulers of Nubia (Punut), during the reign of the fourth Ramesses, locked up his land and made a will that the revenue of that land was to be used for buying a calf every year and sacrificed to his soul after his death. In the Roman era, the government appointed a public servant to oversee the execution of the endowed properties, and the pre-Islamic Arabs had houses of worship and temples where they stored what was offered as gifts then use it as endowments (Baqutayan et. Al., 2018). Cizakca (1998) concluded that Islam had adopted this from other civilisations such as the pre-Islamic Arabs, Ancient Rome, Greece and Mesopotamia. This is because of the absence of any particular mention of Waqf in the Quran except for the 
general promotion of equitable and just income distribution, the doing of good and charitable deeds and mutual cooperation among the society IHTIFAZ - JIEFB

especially the Muslims themselves. Likewise, in the Hadith but, the scholars have similised Waqf with a continuous charity to legitimize its practice. A famous one was narrated by Abu Huraira that the Prophet peace be upon him had said, "When a human being dies, his or her good deeds also come to an end, save three things (that they leave behind): (first) a perpetual charity (Sadaqa jariyah), (second) any beneficial knowledge, and (third) a pious child praying for him or her."

Waqf in Islamic civilisation started with the first known mosque i.e Mosque of Quba that was built upon the migration of the Prophet peace be upon him from Mecca to Medina in 622 CE. The second one was the Mosque of the Prophet, also in Medina and in the same year. The examples mentioned earlier are purely religious. Islamic Waqf extends beyond that. The uses of Waqf are flexible and diverse so long they comply with the Sharia and can sustain over long periods.

A notable example of philanthropic Waqf is the Well of Uthman (may Allah be pleased with him) or Bayruha in Medina in the same year when the two mosques were built. The well originally belonged to someone who was selling water at ridiculously high prices, depriving the poor Medina residents of access to drinkable water. Knowing this, the Prophet peace be upon him proclaimed that the person who would buy the well and make it an endowment to the residents would be guaranteed Paradise. Uthman (may Allah be pleased with him) set out immediately to get the well and did so in two instalments of 38,000 silver dirham each time. He later endowed the well as ordered by the Prophet peace be upon him, letting anyone fetch water from it regardless of the person being Muslim or otherwise without any payment charged for it. Some scholars believe that Waqf of philanthropic nature was initiated by Umar (may Allah be pleased with him) instead of while others opine that the Waqf made by him was more of family Waqf. A Hadith that is recorded in Sahih Muslim narrates the story: "Ibn Umar reported: 'Umar acquired land in Khaibar. He came to Allah's Apostle peace be upon him and sought his advice in regard to it. He said: "Allah's Messenger, I have acquired land in Khaibar. I have never acquired more valuable for me than this, so what do you command I do with it? Thereupon the Prophet peace be upon him said, "If you like, you may keep the corpus intact and give its produce as Sadaqah." So, Umar gave it as Sadaqah declaring that the property must not be sold or inherited or given away as a gift. And Umar devoted it to the poor, to the nearest of kin, to the emancipation of slaves, to wayfarers and guests, and in the way of Allah." Therefore, these first few Waqf acts kickstarted its development in Islamic finance. Today, many new forms of Waqf have been established that include liquid assets Waqf, Sukuk Waqf and corporate Waqf.

Waqf is an effective instrument that Islam has propounded to eradicate poverty and improve the socio-economic condition of the 
Muslim society. Explaining further on this, Cizakca (1998) said that a proper Waqf system in a state could cut government expenditure significantly, thus reducing budget deficits and debts which would later lower the rate of interest. With a lower rate of interest, private investment would grow and thereafter, poverty would gradually dissolve. determined differently, depending on the country's stage of development, policy objectives, and administration. Micro and small enterprises are identified as those having fixed capital or the number of workers under certain threshold levels. On survival, Microenterprises constitute small business and stores, cottage industries with transport services. Three broad categories of economic activities that could be identified namely, production, trading, and providing transport services. In production, the poor may be involved in agricultural or non-agricultural activities. Includes small business, and selling specific items like vegetables, fish. Providing transport services could be through rickshaws, boats, or motor vehicles.

To alleviate the poverty, Elgary (2004) proposed to provide a source of financing for the poor by incorporating to the concept of qard hasan (interest-free loan). he suggested the capital injection of the bank would come from the waqf donated by Muslim where the bank provide the qard hasan financing. The experts support the suitability of the integrated cash waqf micro enterprise investment model in providing financial services to micro enterprises Asmy (2018). The idea of waqf as the source of financinf also supported by Lahsasna (2010) who argued that cash waqf can enchance the access to finance for SMEs in Malaysia. It is expected to increase the GDP and play an important role in the socioeconomic development. A study conducted by Tohirin (2010) in Indonesia, also found that cas waqf can be a solution for Indonesia's SMEs who have lack access to the formal banking institution.

A few limitations that need to be highlighted include, growth in Microenterprises or small organisations may be an important method for employment generation and development of poor countries. The high population growth rate and limited employment opportunities in the agricultural sector and the modern manufacturing sectors leaves a vast majority of the labour force without productive employment. Therefore, it concluded that Microenterprises have played a significant role in employing the surplus labour force productively. Generating employment, a World Bank study (1978) points out the advantages of Microenterprises as increasing the aggregate output, enabling the efficient use of capital and labour, and improving the distribution of income.

Nevertheless, it was mention that microentrepreneur's lack of collateral due to poverty could increase the moral hazard problem. These barriers would make an assessment of projects and monitoring the use of loans very costly. Furthermore, as the size of the loan 
for Microenterprise is small, the administering cost of loans will be increasing. These economic factors make it impossible for traditional financial institutions to offer credit to Microenterprises. Therefore, the problems of financing pointed out above become more acute in the case of Microenterprises run by impoverished. First, the linking approach under which conventional financial institutions are linked to the target group (the poor) through some intermediary like a government agency, a non-government organization (NGO) or a local group. Another approach is to provide microcredit through specialized organizations, like NGOs, government agencies, cooperatives, and development finance institutions. Almost all of the financing for Microenterprises in recent times has come from the latter kind of institutions.

\section{Waqf and Poverty Alleviation}

The goal number one in the United Nations' Sustainable Development Goals is reducing poverty. According to the UN, poverty is more than low income and resources to a sustainable livelihood. It also includes hunger and malnutrition, limited access to education and other essential services, social discrimination and exclusion as well as the lack of participation in decision-making.

Poverty is a universal problem, so much so that a vast majority of the world population suffers from poverty. According to Sadeq (2002), there are four variables related to poverty, namely income level, education, health, and infrastructure. Such an approach has been taken to tackle this poverty problem by the international organization. These variables were chosen to be related to poverty because logically, poverty leads to a low level of education (poverty causes illiteracy). The poor people also have poor health because they are having lack of access to nutritious food, medical care, and again their productivity is low due to poor health, and hence they are poor. Low productivity leads to low income. Sadeeq suggested in his paper that reducing poverty program should address the mentioned variables. If the four variables can be resolved, it is believed that people will gain their welfare and living in a balanced economy.

Islam provides a comprehensive framework to deal with poverty; one of them is through charity. In Islam, there are several kinds of charity, they are; compulsory charity (zakah and fitrah), Optional charity (Sadaqah), and perpetual charity: Waqf. The compulsory and optional charities might help to eradicate the poverty through redistribution concept, while Waqf might enhance the capability of the poor to take care themselves through providing access to education, health, and so on.

Waqf was created during the lifetime of the Prophet (Pbuh). The Waqf of the Islamic community in the era of Prophet Muhammad (PBUH) and his companion (Caliphate) fulfilled the needs of the Muslim society at that time, whether it is for charity or jihad for the sake of Allah. The 
purpose of creating Waqf varied from the 2nd century after Hijrah to include social, scientific, and religious life, Baqutayan et al., (2018).

According to Saadallah, Abu al-Qasim, (1998) in the study conducted by Baaqutayan et al., (2018), "Waqf is one of the most important aspects of Islamic civilization; it is a foundation that expresses the will of the

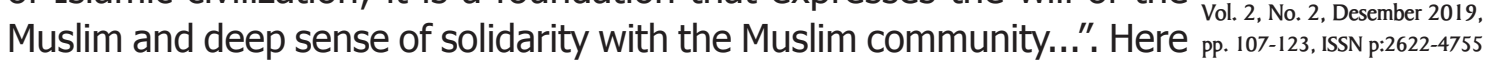
inferred that the development of Waqf in the Muslim world was because of strong religious beliefs and charitable desires.

The historical study by Çizakça (1998) mentioned that the Waqf system contributed significantly to another significant economic problem: employment related to the productivity of the society. The fact has revealed that the implementation of Waqf reduced the unemployment ratio from $12.68 \%$ in 1931 , to $0.76 \%$ in 1990 . Indeed, the Waqf system appears to have ceased being a significant source of employment in the Turkish Republic.

In the study conducted by Hassan (2010), there are two strategies to eradicate poverty. First is through an indirect strategy which to formulate a macroeconomic policy framework to reduce the unemployment rate and increase per capita income. Second is through a direct strategy that targets the poor people and provides them with access to education, health, and financing. He mentioned that Indonesia, Malaysia, and Thailand are examples of a country that have implemented indirect strategies to alleviate poverty. In contrast, Bangladesh is an example of a country that has implemented the direct policy application where the government and non-governmental organizations provide services targeted to the poor.

Islam defines poverty as a state whereby an individual fails to fulfil any of the five basic human requirements of life or in another word named Maqashid Al Shariah: religion, physical self, intellect or knowledge, offspring, and wealth. Every individual is different in term of their ability to sustain their life. Thus, even though individuals are provided with equal opportunities, the economic status of two individuals may not be equal.

The Islamic approach to poverty alleviation would ideally involve a set of antipoverty measures. They are: increasing income level with pro-poor programs, achieving an equitable distribution of income and providing equal opportunities for all social segments. Hassan (2010) argued that Perpetual (Awqaf) might help to eradicate the poverty by improving non-income aspects of the poor such as health and education as well as increasing their access to physical facilities, resources, and employment.

\section{Waqf Based Microfinance Role in Reducing Poverty}

The Islamic financial sector plays an essential role in society by providing finance to the poor to increase their income and wealth. 
Specialized poverty-focused MFIs provide much-needed finance to microentrepreneurs increasing their income levels and wealth

A study conducted by Ahmed (2007) seeing that the small-scale enterprises are playing an important role to increase employment and reduce poverty. Given the problem that there is a need for social financial intermediation of funds for the microentrepreneurs, he argued that MFIs formed to provide the poor with their much-needed finance. Given this nature, most MFIs have a social development program along with its credit facilities.

Providing the economic analysis of microfinancing, Ahmed argued that MFIs might face some problems to sustain its function and reaching the poor. Some obstacles include; mitigating the credit risk, solving moral hazard problem where the borrower failed to pay the loan because of misusing the fund, and its economic viability. Lack of the fund also has other detrimental implications where the MFI cannot hire and pay the sufficient worker. That might threaten the sustainability of MFIs. Therefore, Ahmed suggested Waqf based Islamic MFI to solve the problem.

Waqf based microfinance might mitigate the risk by holding a combination of low risk fixed income assets along with microfinancing activities such as investments and Qard. Moral hazard problem also might be resolved through the financing using Murabahah or Bai' Muajjal or Ijarah. These instruments involve a real transaction, and instead of cash being given out, asset/good is exchanged. Thus, the financing will be ensured to be used in productive spending. As the bulk of the Waqf-based Islamic MFIs funds will come from Waqf endowment, the financing costs of these institutions will be significantly lower which will improve the financial viability of the institution.

Sadeq (2002) argued that there are two dimensions in involving Waqf into the institution activity, they are; making an endowment of Waqf and administration of Waqf. He proposed a mechanism to make Waqf an effective institution of poverty alleviation to establish and support such projects by making it an organized voluntary activity. The institution of Waqf will not be able to do much in its voluntary nature in the implementation of reducing poverty program. This is because a planned program will need specific planned projects, while the planned projects may require a considerable sum of investment which individual or waqifs may not afford it.

Providing this issue, Sadeeq propose a mechanism to make Waqfan effective institution of poverty alleviation by establishing an organized voluntary activity. The proposed project will be as explained; The Waqf institution will issue Waqf certificates of different denominations to fund the projects. So, individuals or institutions may buy them and finance the projects. This project will be the primary project. Later, the author suggested creating a secondary project which might help in maintaining 
the operational and other costs of the primary project. Thus, the Waqf institution can sustainably alleviate poverty.

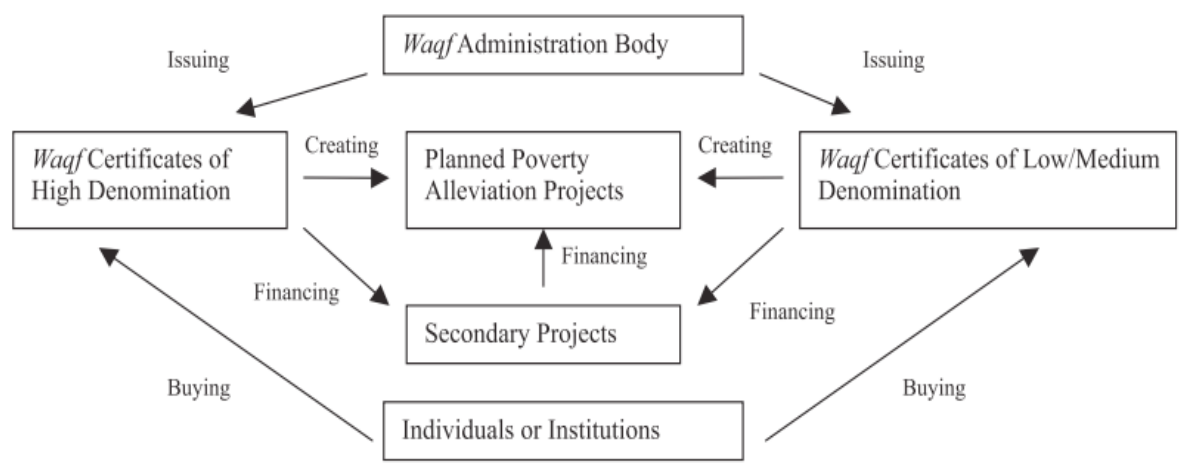

Figure 1: Proposed Waqf Microfinancing by Sadeeq (2002)

In the proposed framework by sadeeq, important and large poverty eradication program may be financed by raising cash Waqf in a planned way. Some projects may include income-generating projects, medical facilities, and infrastructure. Such projects are essential to reduce poverty as subjected to the problem stated by Ahmed (2008)

According to Saikh, Ismail, and Shafiai (2017), under Waqf, the waqif (donator) dedicates an asset for a permanent societal benefit because Waqf can be in the form of building institutions, schools, hospitals, etc. It provides flexibility in fund utilization as compared to zakat. Zakat fund might be utilised for a specific category, while Waqf can provide more welfare services and beneficiaries to Muslims and also non-Muslims.

With regards to the management, administration and governance aspect of Waqf in contemporary times, many scholars also highlight the importance of professional management and transparent administration of Waqf for effective results. An effective measurement system for waqf institution is suggested by Noordin et.al. (2017) promoting good governance and ethical management Another important element in Waqf institution is the sustainability for running its function. Sustainability is supported by profitability. Therefore, seeking profit can help the institution to expand and sustain the social service.

Raimi et.al. (2014) found that zakat and waqf is a plausible model as Corporate Social Investment which could be deployed to poverty reduction in a number of ways ranging from training, microcredit support for SMEs, apprenticeships, providing welfare support services to the poor, marginalised communities and other economically disadvantaged group.

Saikh et al., (2017) recommend some improvement areas to increase the effectiveness of Waqf institution in contemporary applications. The recommendations are related to the adoption of the development of digital technology, highlighting the portion of the contribution, tax 
incentives, social awareness and simplification of the laws pertaining to Waqf.

IHTIFAZ - JIEFB

Islamic microfinance helps to finance the poor because it provides credit without collateral. The traditional micro-finance is also facing high default risk, high operational costs, and low returns. Hassan (2010) criticized the weakness in traditional microfinance such as charging high fixed interest rates, credit diversion, credit rationing and nonconformity which contradicts with the Islamic value. He proposed a combination of Zakat and Waqf based microfinance in an institutional setup. The IMFIs may use Zakat funds for two purposes: to fulfil basic needs and to provide capital investment so that a member could start a micro-business. However, Awqaf funds could be used as a source of funding as well. From Awqaf funds, both capital investment and working capital investments could be made. The distribution of fund shall be allocated among different stakeholders since both sources of the fund has a different nature. This integrated model will contribute to reducing poverty by combining all three approaches:

- Positive measures (like increasing income growth through the development of micro-business for the poor)

- Preventive measures (through ensuring functional re-distribution among factors of productions)

- Corrective measures (engaging Zakat and Awqaf).

The research conducted by Pramanik, A., Mohammed, M. O., Haneef, M.A., (2015) comprises six components, they are Waqf, Islamic microfinance, human resources, Takaful, project financing and poverty alleviation, and then to validate and test the IWIM (Integrated Waqf based Islamic Microfinance) model in the three selected countries; Malaysia, Indonesia, and Bangladesh. The study found that the major challenges faced by Islamic Microfinance Institutions are including high and exploitative interest rate leading to over-indebtedness, limited products, lack of Shari'ah compliance and cultural milieus, outreach, and scaling up.

\section{ISSUES AND GAPS}

\section{Integrated Waqf Based Microfinance}

A microfinance provider in Indonesia namely Baitul Mal wa Tamwil (BMT) has been an effective provider in alleviating the poverty by enabling the poor to have access to credit. However, Wulandari \& Kassim (2015) found that BMT is facing several issues and challenges such as Maintaining subsidy stability is a challenge for BMT sustainability, screening process, training and default issues.

Pramanik et al. (2015) have conducted a research project that covered three Organization of Islamic Cooperation's member countries, 
namely, Malaysia, Indonesia and Bangladesh. The research aimed at exploring the possibility of integrating the institutions of Waqf with microfinance model to alleviate the poverty issue in the said countries. The study highlighted that there were initial four critical components of the IWIM model namely (i) Waqf; (ii) microfinance; (iii) human resource and (iv) Takaful. Under this model, Waqf was considered as a direct source of financing for developing and implementing the Islamic microfinance and human resource development. The study also supported by Haneef, et.al. (2015) who argued the significant relationships between IsMF and takaful, waqf resources and human resource development, takaful and human resource development, IsMF and human resource development and, waqf resources and project financing

Meanwhile, Islamic MFIs would complement their operations with Takaful services. This would help them in promoting affordable financing, human resource development and income/asset security for the poor people and eventually alleviate their poverty situation. As the four critical components mentioned in their study, they proposed an illustration of the integrated Waqf based model as below.

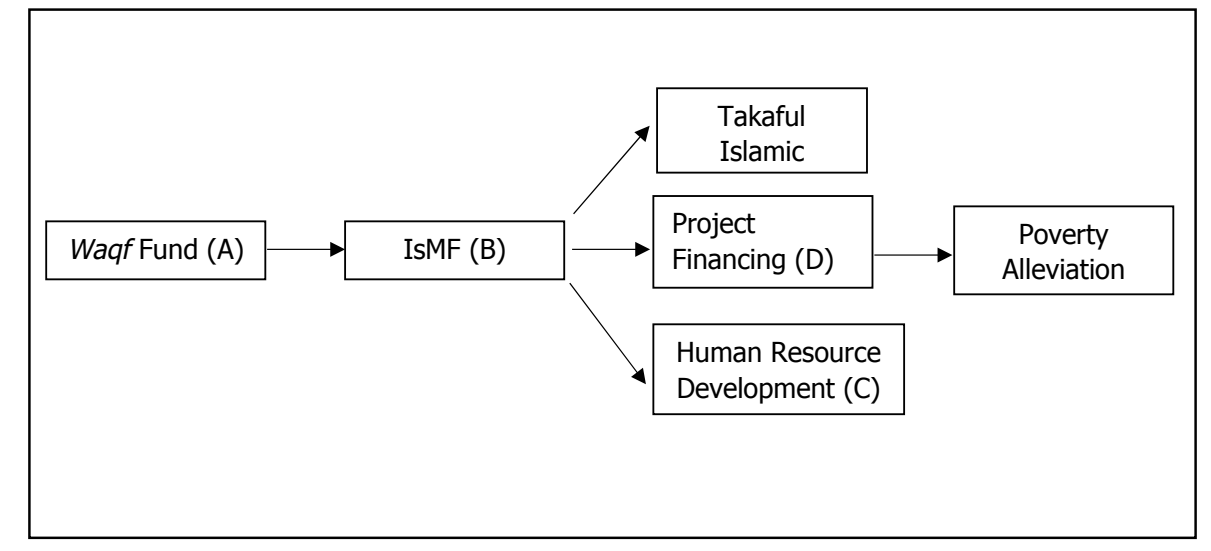

Figure 2: Integrated Waqf-based Islamic Microfinance (IWIM) by Pramanik et al. (2015)

The explanation of the diagram as follow:

A. Waqf funds can be used to reduce the cost of capital for expanding Islamic Microfinance.

B. Islamic microfinance can offer Takaful coverage, project financing and human resource development programs.

C. Human resource capacities acquired can subsequently complement proper project implementation.

D. Successful implementation of the funded project is expected to contribute towards poverty alleviation.

E. Takaful coverage is expected to mitigate the financing and family risk of the poor. 
Ahmed (2007) highlighted in his study that there were three fundamentals problems concerning operations and sustainability of IHTIFAZ - JIEFB Waqf-based Islamic MFIs as following:

1. Credit risk

Given its nature, the lack of physical collateral in the financing scheme may generally increase the credit risk to the institution. Nevertheless, this can be mitigated via an effective monitoring system in place such as a weekly meeting which provides an avenue to detect any issue or problem faced by the scheme members as early as possible. In addition, this risk can also be mitigating through social collateral of groups and weekly repayments. Group-based microfinancing acts as social collateral to reduce the credit risk that exists in financial intermediation. The peer pressure from the group members and the centre provides a low cost and effective way of ensuring repayments and thus avoiding the default situation. Besides, it is more practical and more accessible for the poor to pay small weekly instalments instead of a large lump-sum amount when the financing is due.

2. Moral hazard Problem

Upon the disbursement of the funds, moral hazard problem such as misuse of the funds other than what it intended to be utilized for, need to be tackled to ensure the effectiveness of the scheme/programme. When the financing funds are used for non-productive purposes, this increases the chances of default among the scheme's members. Typically, under the standard or conventional microfinance scheme, the monitoring initiatives to mitigate this risk are relatively costly. Given that the operating cost allocation of Waqf-based microfinance is quite low, this risk may become an obstacle for the future growth and development of the scheme. Nevertheless, by using Islamic mode of financing such as Murabahah, Bai-muajjal or Ijarah (leasing), the Islamic MFIs can to a certain extent mitigate this moral hazard risk. These instruments involve real transaction and instead of cash being given out, which asset or good is being exchanged. As a result, this will eliminate the opportunity of diverting the funds for non-productive uses other than that what it intended for.

3. Economic Viability

Ideally, microfinancing would be a "win-win" situation, provided that the MFI operates at a profit and the poor community benefit from the financing scheme. However, due to lack of fund mobilization and the high administrative cost, most MFIs are not economically viable. As the Waqf-based Islamic MFIs funds will come from Waqf endowment, the financing costs of these institutions will be significantly lower than their 
conventional counterparts. Given the nature of the Waqf fund that contributors expect no returns. While Islamic MFIs will pay returns on funds coming from external sources like deposits and beneficiary savings, the Waqf component of funds will significantly reduce the financial costs and improve the financial viability of the institution.

Vol. 2, No. 2, Desember 2019. pp. 107-123, ISSN p:2622-4755

The empirical research conducted by Pramanik, et al. (2015) is using three entities from Malaysia, Indonesia, and Bangladesh. The entities involved under the research were (i) Amanah Ikhtiar Malaysia (AIM); (ii) Baitul Maal Wat Tamwil (BMT) in Indonesia; and (iii) The Rural Development Scheme (RDS) of the Islamic Bank Bangladesh Limited.

Pramanik et al. (2015) argued that that the mobilization of funds through Waqf (as well as from Zakah, Sadaqah) indeed can be an additional and important source of funds to assist in poverty alleviation efforts in the OIC countries. Meanwhile, the implementation of integrated Waqf based Islamic microfinance will be quite challenging. This obstacle can be overcome through concerted efforts by the relevant institutions both at the national and multi-national or international level.

Based on the literature review, Pramanik et.al. (2015) concluded some issues that might be the gap in the Waqf based microfinance issue. This further can be an interesting topic for developing the research on microfinancing issues. The findings that might be highlighted further discussion include:

i. The financial flow of IWIM model must go with the real transaction in terms of the development of skills, motivation and infrastructure for poverty alleviation.

ii. The proper guidance, training on product development, marketing and other skill must be taken in accordance of the different level of poverty. In addition, the concept of project financing can be more effective in creating wage employment for the poor community.

iii. Project financing under the scheme can be in the form of small/ medium/large projects subject to the period, place and nature of the project financed by Waqf/Zakah/charity funds. It can follow the principles of venture capital which emphasizing on the investment which yielding higher returns

iv. Islamic MFIs and NGOs can collaborate together in implementing IWIM. NGOs will utilize the fund for developing infrastructure, training centres, schools and health care centres. Meanwhile, the Islamic MFIs can also distribute financing for more incomegenerating activities within the poor community

v. The Islamic microfinance can partner with the business enterprise in providing many services like training, education, and health care. The proposed model can play a central role in this regard. 
vi. In addition to using Waqf as a source of funding, the proposed IWIM model can also focus on various other sources of financing such as charity, donation and public funds for social assistance.

The findings from the study by Pramanik, et al. (2015) suggests that Waqf has substantial untapped potential as a source of funding for Islamic Microfinance in reducing the cost of capital. This potential will be more enhanced when it is combined with human resource development, Takaful provision and improving capacity on project financing. However, there is a need for more exceptional education and awareness among the stakeholders to realize and unlock this potential.

Although IWIM model is relevant to be implemented in emerging countries, it must pay attention varying with the environment. Some aspects that might need attention to implement integrated Waqf model are:

- $\quad$ Funding Agencies: It is possible to utilize other sources of funding rather than Waqf, such as those from government, charitable organization, as well as international development financing institutions such as the Islamic Development Bank.

- Implementing Agencies: This agency is expected to be an Islamic microfinance institution. However, it is not limited to other institution such as public organizations for social assistance programs, non-governmental organizations (NGOs) and even Waqf institutions

- Takaful: This instrument needs to be used not only to cover investment risks, i.e., to ensure payment of financing to funding agencies but also to cover risks confronting individual and family businesses.

- Human resource development: Poverty is a long run project that might need o give adequate attention to education and training programs for the recipients of Islamic microfinance.

In order to successfully implement the integrated Waqf microfinance, awareness should be created among stakeholders through an effective media campaign. Good governance is a critical factor for successful implementation. If the model is implemented in a setting where institutional quality and level of governance are high at the local and national level, then the proposed IWIM model, like other similar projects, will be more effective in implementation as well as in achieving the goal of poverty alleviation.

\section{DISCCUSSION \& CONCLUSION}

Poverty and income inequality are universal problems, especially for emerging countries. United nation made eradicating poverty as the number one goals to emphasize that poverty is a serious problem that 
every country should consider. Islam provides tools that can be used to alleviate poverty. Waqf is believed to be an effective tool as it has proven to give a huge impact on the economy since the Prophet era. Cizacka (1998) also stated that Waqf could reduce poverty in Turkey by reducing the unemployment rate by $11 \%$ in 1990 . direct and indirect strategy. The indirect strategy takes place in governing the macroeconomy policy to increase income per capita. Meanwhile, the direct strategy is targeting the poor by providing access to education, health and finance. While governing the country and macroeconomy is not easy as flipping hand, the direct strategy is observed to give more opportunity for everyone to contribute to reducing poverty. The direct strategy may use Islamic tools such as Zakat, Waqf, and Sadaqah to achieve a sustainable society.

Waqf based microfinance offers the model that might help to alleviate poverty. To achieve this goal, the Islamic microfinance might combine the good governance within the organization structure and financing scheme through Waqf source of fund. The framework proposed by Sadeeq (2002) applied to the Islamic microfinance whereby issuing the Waqf certificate and established a planned primary and secondary project which supporting each other to eradicate the poverty. However, developing the Waqf based microfinance is not limited on Sadeeq's mode, Pramanik et al. (2015) also proposing the IWIM model by projecting on takaful coverage, project financing, and human resources development program.

Based on the author's observation, there is a possibility in combining both models proposed by Sadeeq and Pramanik. Proposed model by Sadeeq (2002) provides a comprehensive model involving many stakeholders, primary project and supporting project. Meanwhile, Pramanik et al. proposed to use Waqf fund to win the cost leadership and providing project financing as well as human resource development program. Both frameworks can collaborate in the form of its project on building access to education, health, and finance a well as human resource development to make the microfinance model more sustainable.

Although Waqf based microfinance offers the solution to eradicating poverty, the microfinance institution might find some obstacles in running the project. Some problem that might occur in Islamic microfinance institution is related to credit risk, moral hazard, and economic viability. The MFIs also suggested adjusting their development and operation based on the digital economy trend to compete with its conventional counterpart and achieve the poverty eradication goals. 


\section{REFERENCES}

IHTIFAZ - JIEFB

Baqutayan, S.M., et.al, (2018), "Waqf Between the Past and Present", Mediterranean Journal of Social Science, Vol.9 No.4, pp.149-155.

Çizakça, Muratz (1998), "Awqaf In History and Its Implications For Modern Islamic Economies" Islamic Economic Studies Vol. 6, No. 1.

Habib, Ahmed. (2002), Financing Microenterprises: An Analytical, Study of Islamic Microfinance Institutions, Islamic Research and Training Institute Journal, Vol. 9, No.2.

Hassan, K. (2010), "An Integrated Poverty Alleviation Model Combining Zakat, Awqaf and Micro-Finance" Seventh International Conference - The Tawhidi Epistemology: Zakat and WaqfEconomy, Bangi 2010.

Pramanik, A., Mohammed, M. O., Haneef, M.A., (2015), "Integration of Waqf and Islamic Microfinance for Poverty Reduction: Case Studies of Malaysia, Indonesia, and Bangladesh". SESRIC and International Islamic University Malaysia, Gombak, Kuala Lumpur.

Sadeq, AbulHasan M., (2002), "Waqf, perpetual charity and poverty alleviation", International Journal of Social Economics, Vol. 29 Issue: 1/2, pp.135-151

Shaikh, S.A., Ismail, A. G., Shafiai, (2017), "Application of Waqffor social and development finance", ISRA International Journal of Islamic Finance, Vol. 9 Issue: 1, pp.5-14.

Asmy, M. (2018), "A qualitative inquiry into cash waqf model as a source of financing for micro enterprises", ISRA International Journal of Islamic Finance, Vol. 10 No. 1, pp. 19-35.

Raimi, L., Patel, A., Adeopo, I., (2014), "Corporate social responsibility, Waqf system and Zakat system as faith-based model for poverty reduction", World Journal of Entrepreneurship, Management and Sustainable Development Vol. 10 No. 3, pp. 228-242.

Noordin, N. H., Haron. S. N., Kassim, S. (2017), "Developing a comprehensive performance measurement system for waqf institutions". International Journal of Social Economics Vol. 44 No. 7, pp. 921-936

Elgari, M.A. (2004), "The Qard Hassan bank", paper presented at the International Seminar on Nonbank Financial Institutions: Islamic Alternatives, 1-3 March, Kuala Lumpur.

Tohirin, A. (2010), "The cash waqf for empowering the small businesses", paper presented at the 7th International Conference on the Tawhidi Epistemology: Zakat and Waqf Economy, Bangi.

Lahsasna, A. (2010), "The role of cash-waqf in financing micro and medium-sized enterprises", paper presented at the 7th International Conference on the Tawhidi Epistemology: Zakat and Waqf Economy, 6 January, Bangi, Selangor. 
Wulandari, P., Kassim, S. (2015), "Issues and challenges in financing the poor: case of Baitul Maal Wa Tamwil in Indonesia", International Journal of Bank Marketing Vol. 34 No. 2, 2016 pp. 216-234.

Journal of

Haneef, M. A., Pramanik, A., Mohammed, M. O., Amin, M. F., Muhammad, Islamic Economics, Finance, A. D., (2015), "Integration of waqf-Islamic microfnance model for poverty reduction The case of Bangladesh". International Journal of Islamic and Middle Eastern Finance and Management Vol. 8 No. 2, 2015 pp. 246-270.

Vol. 2. No. 2, Desember 2019 e:2622-4798
.

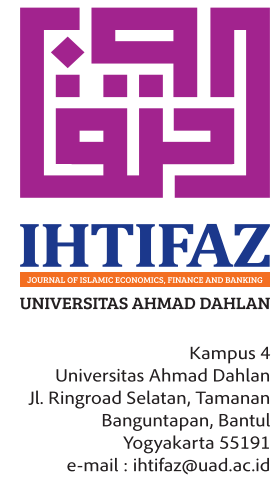

